Rupantaran : A Multidisciplinary Journal

Vol. IV : pp 1-10, October, 2020

ISSN : 2091-0061

https://doi.org/10.3126/rupantaran.v4i1.34012

Research Management Cell (RMC)

Dhankuta Multiple Campus, Dhankuta

Tribhuvan University, Nepal

\title{
Enriching English in School Education: Some Problems and Principles
}

Ambika Prasad Poudel ${ }^{1}$

Email:poudelap@gmail.com

\section{Abstract}

English is a widely used language in international communication. It is a storehouse of knowledge that most of the books, and journal articles have been published in English, and it is the dominant language in the Internet. Realizing this fact, the government of Nepal has made English one of the core components of school education curricula. However, teaching and learning of English in the schools in Nepal has been influenced by several problems. Using systematic literature review as the methods, this article makes an attempt to highlight the major problems that exist in teaching and learning of English in school education in Nepal, and points out some principles for enriching English in the learners. This study has been expected to add at least some insights to those who are interested in enhancing English education in Nepal.

Key Words: collaborative tasks, instructional materials, language exposure, lingua-franca, research synthesis

\section{Introduction}

English is widely spreading worldwide at present. It is believed that English has become a storehouse of knowledge because many of the published books, journals, periodicals, newspapers, and websites are in English (Harmer, 2007). Therefore, English has been one of the very essential means for grasping ideas from its rich vocabulary and written literature. It is the instructional language used in science and technology, business, literature, politics, and in education.

In multilingual country Nepal, altogether 123 languages are spoken as mother language and the number of people speaking English as their mother tongue is 2032

1. Mr. Poudel is a Lecturer of English Education at Tribhuvan University, Dhankuta Multiple Campus, Dhankuta. 
(CBS, 2012). It is just $0.008 \%$ of the total population. However, English has been an essential part of modern Nepalese people (Bhattarai \& Gautam, 2005, Khati, 2013). English appears not only in the fields like education, communication, business, health, transportation, and science and technology, but also in simple day to day interactions of the people. It is becoming gradually difficult to survive as modern citizen without English. Though English is used for exchanging information, ideas, inquiries etc. as other languages, it plays significant role as an international language that establishes channels of communication with the rest of the world (Malla, 1977, p. 12). In this way, English is a lingua-franca for different speech communities on the one hand, and on the other hand, it is becoming integral part of the everyday life of modern societies in the day-to-day activities such as listening to radio, watching television, using mobile phones and computer. Thus, English language has become a window to a world through which individuals can peep the world's happenings. Discussing the role of English, Bhattarai (1995) writes:

English has become an indispensable vehicle to the transformation of modern civilization into the nation. It is the passport through which one can visit the whole world and one who knows English, can enjoy the advantages of a world citizen. (p. 226)

English language has significant influence in the life of world citizens at present in both developed and developing countries including Nepal. Some of the important reasons why English is needed in Nepal can be pointed out in summarized form. English is important in Nepalese societies for: (i) taking part in international communication, (ii) receiving formal education, (iii) widening knowledge through further studies, (iv) taking part in national and international business, and (v) understanding science and technology.

Therefore, the government of Nepal has made a provision of studying English language (and English language teaching and learning) as one of the core components of Nepalese school-educational system (CDC, 2007, p. 44). It is not only the compulsory subject from primary up to bachelor level students in the government sector educational institutions, but also one of the popular optional subjects for the students in the country (Bhattarai, 2006, Shrestha, 2008). It is the medium of instruction, and the important slogan of student attraction in most of the institutional schools in Nepal (Shrestha, 2008).

As mentioned earlier, the government of Nepal has given important priority to teaching-learning of English in school education. However, the SLC result shows that English is one of the subjects in which many of the students fail. English is considered to be one of the more difficult subjects (Mathema \&Bista, 2006); and over $90 \%$ of the students who could not pass SLC fail in English, Maths and science 
(Budhathoki et al., 2014). There are several causing factors of such failure of the students. Therefore, it is essential to study and explore the reasons and problems behind such results so that some insights can be developed in formation of future plans. Likewise, it is equally essential and worthwhile to highlight some principles of teaching English for the improvement of existing situation. Therefore, this study makes an attempt to highlight the major problems that exist in the teaching and learning of English and give some principles to enrich and improve English in the learners. The main research questions in this study were: (i) what are the major challenges in teaching and learning of English in school education in Nepal? and (ii) what are the guiding principles for enriching English in the learners?

\section{Methods and Materials}

This study was guided by evidence-based approach, and literature review methods. A literature review method can be described as a way of collecting and synthesizing previous works (Tranfield, Denyer, \& Smart (2003). Literature review methods are useful to make an overview of certain issues or research problems.

Among different literature review methods, this study adopts 'research synthesis', often called 'systematic review' as the method of study. Systematic reviews (SRs), according to Lame (2019, p. 1) are "a way of synthesizing scientific evidence to answer a particular research question in a way that is transparent and reproducible". Likewise, Cooper, Hedges, \& Valentine (2019, p. 6) opine that research synthesis is a broad array of integrative activities that attempts to integrate research studies for creating generalizations from both quantitative and qualitative research works. Similarly, to Liberari et al. (2009), a systematic review is a research method and process for identifying and critically appraising relevant research, by collecting and analyzing data from said research (Liberati et al., 2009). Emphasizing the importance of SRs, research scholars opine that single studies taken in isolation are often seriously misleading, and that synthesis of the results of multiple studies provide better information than the results of a single study (Petticrew \& Roberts, 2006, p. vi; Littell, 2006 p. 1). The main steps in research synthesis methods are formulating the research problem, searching literature, gathering information from studies, evaluating quality of studies, analyzing and the studies, and interpreting the results (Cooper, Hedges, \& Valentine, 2019).

Unlike single studies, systematic reviews are a method of advancing knowledge by making sense of a large body of information. According to Snyder (2019, p. 336), "If the purpose of the review is to investigate and synthesize evidence of the effect of a specific factor, a systematic review approach should be used". Systematic reviews enable the researchers to get into conclusion through comprehensive literature 
review (Tranfield, Denyer, \& Smart (2003). In this study, related previous literature (such as Umar \&Jalil, 2012; Salehi \&Salehi, 2012; Goktas, Gedik \& Baydas, 2013; Thapaliya, 2014; Shrestha, 2008; Giri, 2010; Bhattarai, 2006; NIRT, 2017; Budhathoki et al. 2014; MOE, 2013; Ertmer 1999; Brown 2001; Krashen 1982; Pienemann \& Lenzing, 2015;.Erben, Ban \& Castaneda 2009; Gupta 2019; Mathema \& Bista, 2006; UNESCO, 2015; Harmer, 2007; CDC, 2007; Malla, 1977, Bhattarai, 1995; Bhattarai \& Gautam, 2005, Khati, 2013) have been reviewed to analyse and synthesize available books, and journal articles, conference papers consulting Internet and search engines, and physical library. The research works of different scholars as mentioned above have been synthesized to elaborate the concepts of the related issues of the study, and their findings have been interpreted. Besides, the researcher has also incorporated his more than two decades' personal experiences of being involved in teaching-learning of college courses for the description and explanation of the issues of the study.

\section{Results and Discussion}

Exploring the main problems in ELT in school education in Nepal is the main concern of this study. In this section, the main issues of the study have been discussed. Particularly, the problems of teaching English in school education in Nepal, and some of the useful principles to be considered for enriching English have been elaboratively analyzed in the sub-headings to come.

\section{Problems and Challenges of ELTAL in Nepalese Secondary Schools}

There are many responsible factors that cause problems in ELT such as administrative and infrastructures factors such as insufficient infrastructures and technical support, little access to ICT, and class time (Umar \&Jalil, 2012; Salehi $\&$ Salehi, 2012). Likewise, the problems in ELT can be related to training to the teachers, course content, and physical environment (Goktas, Gedik \& Baydas, 2013). As a developing country, English language teaching and learning in context of Nepal is rather challenging, and till now ELT situation is far from satisfactory (Shrestha, 2008) though it is slowly making its progress in the sector of school education. Some of the important challenges in ELT in Nepal have been discussed in the following paragraphs.

Poor physical infrastructures: The physical infrastructures in many of the schools in Nepal are very poor (Thapaliya, 2014; Shrestha, 2008; Giri, 2010). The number of schools with moderately satisfactory infrastructures can be counted in fingers. In some of the schools, the classes do not have adequate number of desks, bench, even the blackboard. Many of the classrooms are too narrow and they are 
uncomfortable for the students in many ways. They do not have the facilities like library, playground, drinking water, latrine, and electricity. Very few schools have availability of modern technologies and ICT infrastructures such as Internet, power supply, e-library, computer lab, and interactive whiteboard.

Insufficient instructional materials: Most of the teachers tackle the problem of insufficient teaching materials (Bhattarai, 2006, Thapaliya, 2014; NIRT, 2017). Many of teachers do not use the teaching materials other than books, chalks and dusters because they do not get any support for their management; and also, because they have over-load with unremitting periods. Using ICTs in teaching learning situation is just an imagination for the teachers in many of the schools. Teaching English in such situations is very much challenging.

Loose administration/supervision: Administrative factor is significant to run any programme well (Umar \& Jahil, 2012), and that the administration should be strong and skillful. The people who are holding the administration in many schools in Nepal are neither skillful nor responsible for quality of education except in a few cases. (NIRT, 2017). Many of them are neither supportive nor are they sincere about the regularity, punctuality, and quality of the employees. Many of the school supervisors appointed are neither the subject experts, nor do they visit the schools and observe the classes so as to provide feedback to the teachers and parents. The administration is found relatively stronger in institutional schools than in community schools.

Worse professional environment: In many schools, the teachers are untrained, and they do not have sound pedagogical skills for teaching (Giri, 2010, Thapaliya, 2014; Budhathoki et al. 2014). Many teachers do not have a feeling that teaching is a profession. They anyway, continue their job, but do not show such responsibility to maintain the quality of education. It is also that the government has not been able to make teaching a prestigious job. Moreover, the situation to have a long temporary job has created a frustration and negligence towards this profession.

Adverse socio-linguistic situation: One of the challenges in teaching-learning English is that the socio-linguistic environment of most of the learners is not English favorable. Their environment, particularly, in case of many of the community schools, does not support in such a way that they are exposed to English. Even inside the classroom the teachers (and even the trained teachers) feel much difficulty to create English interactive environment (Shrestha, 2008) for those linguistically poor students. It is also that, because of upgrading system of examination and evaluation, many students who are very weak in the subjects like English, Math etc., are upgraded to upper classes without required skills or knowledge. At many of the schools, the exposure to English is so low that the students hardly get 40 minutes' exposure to 
English in a day. However, the exposure to English in case of private schools is relatively satisfactory due to their medium of instruction (Bhattarai, 2006, Shrestha, 2008).

As discussed in the paragraphs above, ELTAL in school-education in the context of Nepal, is a great challenge (Bhattarai, 2006; Shrestha, 2008). There are many problems related to teachers, students, administration, and teaching-learning environment. Mostly, the teachers have overload, and that they lack appropriate instructional materials and refresher trainings. The class sizes are often large, and the teachers have to teach the students in poor infrastructure without support of modern technological tools. Many of the teachers are not trained, and teaching English using the traditional methods such as grammar translation and structural drills have been useless investment of time and effort (Bhattarai, 2006; Shrestha, 2008). In most of the community schools, the students study English hardly 45 minutes a day, which is too little exposure to English. In many of the community and institutional schools the students study just a single textbook for a course. They do not consult any other learning materials for widening their knowledge; and that the students are fully teacher dependent for the information/learning resources. Many of the teachers do not have access to Internet and information and communication technologies (ICTs), and that they have little idea if they (ICTs) can support their teaching and learning (UNESCO, 2015). Moreover, there is no interactive and collaborative learning environment. Teacher-student and student-student interaction about a subject is limited within the boundary of 45 minutes' classes. The teachers and the students do not have supportive means to share their knowledge and learning resources as per they need. Collaborative tasks between and among the students are useful but such tasks are rarely conducted because they have little ideas about it; and also, because that they have no such supportive means available. In fact, the environment exists in the schools, and the methods and techniques that are in practice, cannot help the learners to be competent English language users (Bhattarai, 2006).

In fact, quality education is the national goal of education. Recently, the integration of ICTs has been regarded as the supportive policy to make better improvement in the educational achievements (MOE, 2013). However, the problems and challenges discussed above have been major obstacles to have successful achievement of the national goals. Ertmer (1999) categorizes such problems as 'first-order barriers', and such barriers can be eliminated by some strategic policies. Therefore, to improve the existing status of teaching and learning of English some strategic policies are needed to be formulated at institutional or governmental level to address these problems and challenges. Likewise, the teachers and learners need to keep in mind the useful principles of language teaching and learning. Some of these important and useful principles have been discussed in the sub-heading to come. 


\section{Principles for Enriching English}

In many parts of the world, English is being taught and learnt as foreign language. For a foreign language teaching and learning to be successful, it needs to be systematic. Brown (2001) opined that a systematic procedure of language teaching and learning requires cooperation rather than competition, resolution instead of conflict, and understanding instead of prejudice. He pointed out that a foreign language can be practically and particularly be taught and learnt being guided by a set of 12 principles that have been categorized into three main types:

i) Cognitive principles: The cognitive principles are concerned with the learners' cognition in processing and acquiring a foreign language. These principles are related to the mental process and intellectual activities of the language learners. The language learning principles such as principle of meaningful learning, anticipation of reward, intrinsic motivation, automaticity and strategic investment are the types of cognitive principle.

ii) Affective principles: The affective principles are primarily concerned with the affective factors and condition of the learners that are associated with the psychological theories and assumptions. These principles are related to language and culture such as the principle of language ego, self-confidence, risk taking, and language-culture connection.

iii) Linguistic Principles: The linguistic principles are concerned with language and language development and are related to the process and progress of the acquisition of the foreign language features. The principle of native language effect, inter-language, and the principle of communicative competence belong to linguistic principle.

All the children who are not physically or mentally disabled, acquire their mother language subconsciously through a certain stage of development without formal teaching. In case of foreign language teaching and learning too, there is a certain order of language development of the language learners, but they need to be cognitively and psychologically prepared to do so (Krashen 1982; Pienemann \& Lenzing, 2015). Erben, Ban and Castaneda (2009) state that the language teachers cannot change the route of language development for English language learners (ELLs), however, they can affect their rate of language development by providing language acquisition-rich environment. Erben et al. (2009) suggest five principles for creating such effective English language learning environments (p. 16-22). These principles are:

1. Give ELLs many opportunities to listen, read, write, and to discuss oral and written English texts expressed in a variety of ways. 
2. Draw attention to patterns of English language structure.

3. Give ELLs classroom time to use their English productively.

4. Give ELLs opportunities to notice their errors and to correct their English.

5. Construct activities that maximize opportunities for ELLs to interact with others in English.

A good English language teacher needs to have a sound understanding of the approaches, methods and techniques of teaching various skills, aspects, systems and functions of English language. More importantly, as Erben et al. (2009) suggest, English language teachers need to create a language learning environment for helping students gain competence of the English language. According to Ludvigsen and Morch (2010), ICTs are useful for creating student-centered teaching-learning environment. ICTs can be used as the helpful tools to adopt the principles mentioned by Erben et al. (2009).

Gupta (2019) outlines underlying principles for the best practices with an emphasis on EFL students. He has identified seven principles of second language learning that are critical to successfully teaching EFL students.

1. Know your student and motivation to learn the second language

2. Create a welcoming classroom environment

3. Build background knowledge

4. Provide Comprehensible Input by building vocabulary

5. Include frequent opportunities for Interaction and Discussion

6. Use Multiple Modalities during instruction

7. Conduct ongoing review and assessment

The principles discussed above are the general principles concerned with teaching English as a foreign language. These principles are useful in all types of EFL situations including teaching and learning English in school education they help the teachers, educators, and learners to improve and enrich English language skills.

\section{Conclusion}

English is an international language popularly used world wide. In Nepal, English has been considered as one of the essential and compulsory components of school education. At the same time, there are several problems that affect the success of English language teaching and learning. These main problems can be categorized as infrastructure management related, and pedagogical skill development related. To improve the existing practice of English language teachinglearning, and to enrich English of the learners, these problems need to be minimized by the strategic policy of the institution or nation. Likewise, the teachers and the 
students need to keep in mind the cognitive, affective, and linguistic principles which are useful to enhance English language skills.

\section{References}

Bhattarai, G. R. (1995). Methods of teaching English. Kathmandu: Ratna Pustak Bhandar.

Bhattarai, G. R. (2006). English teaching situation in Nepal: Elaboration of the theme for panel discussion in the $40^{\text {th }}$ TESOL conference. Journal of NELTA, 11(1-2),11-16.

Bhattarai, G. R. \& Gautam, G. R. (2005). English language teaching at the crossroads. Journal of NELTA, 10(1-2), 1-5.

Budhathoki, C. B. et al. (2014). Status of SLC dropouts and identifying ways to engaging students in curricular activities. Kathmandu: DOE

Central Bureau of Statistics [CBS], (2012). National population and housing census, 2011. Kathmandu: National Planning Commission Secretariat.

Cooper, H. ; Hedges, L. V. ; \& Valentine, J. C. (Eds, 2019). Handbook of research synthesis and meta-analysis, 3rd edition. New York: Russell Sage Foundation Curriculum Development Centre [CDC], (2007). National curriculum framework for school education in Nepal. Bhaktapur: CDC.

Erben, T., Ban, R. \& Castañeda, M. (2009). Teaching English Language Learners through Technology. London: Routledge.

Ertmer, P. (1999). Addressing first and second order barriers to change: Strategies for technology integration. Educational Technology Research and Development, 47 (4), 47-61.

Giri, R. A. (2010). English language teachers' resource center: A model for developing contexts. Journal of NELTA, 15 (1-2), 64-76.

Goktas, Y., Gedik, N, \& Baydas, O (2013). Enablers and barriers to the use of ICT in primary schools in turkey: A comparative study of 2005-2011. Computers and education 68, 211-222.

Gupta, A. (2019). Principles and Practices of Teaching English Language Learners. International Education Studies; 12( 7), pp 49-57.

Harmer, J. (2007). The practice of English language teaching. England: Pearson Education Limited.

Khati, A. R. (2013). Career gains and identity loss: The effect of English in the Nepali hinterlands. Journal of NELTA, 18(1-2), 77-91.

Krashen, S. (1982). Principles and practice in second language acquisition. Oxford: Pergamon.

Lame, G. (2019) Systematic Literature Reviews: An Introduction. In Proceedings of the $22^{\text {nd }}$ International Conference on Engineering Design (ICED19), Delft, The Netherlands, 5-8 August 2019. DOI:10.1017/dsi.2019.169 
Liberati, A., Altman, D. G., Tetzlaff, J., Mulrow, C., Gøtzsche, P. C., Ioannidis, J. P. A., \& Moher, D. (2009). The PRISMA statement for reporting systematic reviews and meta- analyses of studies that evaluate health care interventions: Explanation and ela- boration. Annals of Internal Medicine, 151,W-65. https://doi. org/10.7326/0003- 4819-151-4-200908180-00136.

Littell, J. H. (2006). Systematic Reviews in the Social Sciences: A Review. Evidence \& Policy 2(4 ): 535-537, doi: 10.1332/ 174426406778881728

Ludvigsen, S. R. \& Morch, A. I. (2010). Computer supported collaborative learning: Basic concepts, multiple perspectives, and emerging trends. Retrieved Sept 28, 2016 from https://www. researchgate.net/publication/228975777

Malla, K. P.(1977). English in Nepalese education. Kathmandu: Ratna Puastak Bhandar. Mathema, K. B. \& Bista, M. B. (2006). Study on student performance in SLC. Kathmandu: MOE

Ministry of Education [MOE], (2013), Information and communication technology in Education, Master Plan 2013-2017. Kathmandu: MOE, GON

National Institute for Research and Training [NIRT] (2017). Nepal Education Sector Analysis. Kathmandu, Nepal: Author

Petticrew, M. \& Roberts, H. (2006). Systematic review in social sciences: A practical guide. USA: Blackwell Publishing.

Pienemann, M. \& Lenzing, A. (2015). Processability theory. In B. van Patten and $\mathrm{J}$ Williams (Eds), Theories in second language acquisition: an introduction. NewYork: Tylor and Francis, pp. 159-179.

Salehi, H. \& Salehi, Z. (2012). Challenges for using ICT in education: Teacher insight: International journal of e-education, e-management and e-learning, 2(1) $40-43$.

Shrestha, P. (2008). ELT, ESP \& EAP in Nepal, whose interests are served? In Krzanowski, Mark (Ed.) EAP and ESP in Developing countries: State of play vs actual needs and wants (pp. 191-210). Canterbury: IATEFL (ESP SIG).

Snyder,H (2019). Literature review as a research methodology: An overview and guidelines. Journal of Business Research, 104(2019), pp 333-339

Umar, I. N., \& Jalil, N. A. (2012). ICT skills, practices and barriers of its use among secondary school students. Procedia-Social and Behavioral Sciences 46, 56725676.

UNESCO,(2015 a). Supporting competency-based teacher training reforms tofacilitate ICT-pedagogy integration: Nepal implementation, progress report. Kathmandu: Education unit UNESCO. 